\title{
EVALUASI KAPABILITAS DAN EFEKTIVITAS ONLINE PUBLIC ACCESS CATALOG (OPAC) SEBAGAI SARANA TEMU KEMBALI DI PERPUSTAKAAN UNIVERSITAS ISLAM NEGERI DI INDONESIA
}

\author{
Marwiyah \\ UIN Sunan Kalijaga Yogyakarta \\ Email : marwiyah.prabowo@gmail.com \\ Labibah \\ UIN Sunan Kalijaga Yogyakarta \\ Email : labibah@uin-suka.ac.id
}

\begin{abstract}
Providing library users with the access to the information sources through informatian retrieval system is an important task of a library. Online Public Access Catalog (OPAC) is one of the information retrieval tools which lets library users know what information is available at the library, and the task of a library to provide its users with such an access is becoming more demanded as its catalogue is developed in the form of online one. This research is intended at identifying the searching and browsing facilities and capabilities of the OPAC of the Library of the State Islamic University. In addition, this research will also evaluate the precision level of the OPAC as a tool to retrieve information, and will examine if the searching facility has any effect on precision level. Based on qualitative data concerning the completeness of the searching and browsing facilities, the researcher tries to look at the effectiveness of the OPAC of the Library of the State Islamic University by taking five of the State Islamic University's OPACs as samples. The result shows that some searching and browsing facilities are not available at the State Islamic University's OPAC, such as menu of retrieval helper, bibliography limited description. And the OPAC with complete facility shows a high degree of precision, while the OPAC with incomplete facility shows a lower degree of precision.
\end{abstract}

Keywords: OPAC, OPAC Evaluation; Academic Libraries; Information Retrieval

\begin{abstract}
Abstrak: Menyediakan akses ke sumber informasi yang dimiliki oleh lewat sarana temu kembali informasi menjadisalah satu tugas penting perpustakaan.OPAC (Online Public Access Catalog) adalah salah satu sarana temu kembali informasi yangberfungsi memberitahu kepada pengguna apa yang dimiliki oleh perpustakaan. Saat ini katalog banyak dikembangkan dalam bentuk online. Penelitian ini bertujuan untuk mengidentifikasi kelengkapan fasilitas dan kapabilitas searching dan browsing pada OPAC perpustakaan Universitas Islam Negeri (UIN) di Indonesia. Selain itu penelitian ini bertujuan untuk mengevaluasi precision (ketepatan) OPAC sebagai sarana temu kembali informasi dan menguji apakah fasilitas searching berpengaruh terhadap tingkat precision.Dengan menggunakan data kualitatis yaitu yang berkaitan dengan kelengkapan fasilitas
\end{abstract}


Marwiyah, Labibah, Evaluasi Kapabilitas Dan Efektivitas Online Public ...

searching dan browsing, maka peneliti mencoba untuk melihat efektivitas OPAC Perpustakaan UIN sebagai system temu kembali dengan mengambil lima OPAC UIN sebagai sampel. Hasil penelitian menunjukkan bahwa ada beberapa fasilitas searching dan browsing yang tidak dimilikioleh OPAC UIN seperti menu bantuan penelusuran,keterbtasan deskripsi bibliografi. Dan OPAC yang memiliki fasilitas yang paling lengkap memiliki ketepatan yang tinggi sedangkan yang memiliki fasilitas paling minim memiliki nilai ketepatan yang rendah.

Kata Kunci: OPAC, Evaluasi OPAC; Perpustakaan Perguruan Tinggi; Temu Kembali Informasi

\section{PENDAHULUAN}

Perpustakaan memiliki fungsi penting dalam dunia pendidikan karena salah satu fungsi perpustakaan adalah menyediakan berbagai sumber informasi untuk masyarakat pengguna. Perkembangan teknologi informasi yang berdampak pada ledakan informasi dengan berbagai format yaitu baik dalam bentuk cetak maupun elektronik tidak mengubah fungsi perpustakaan bagi masyarakat, akan tetapi perpustkaan dituntut untuk selalu bisa menyediakan kemudahan akses informasi bagi pemustakanya melalui berbagai media. Perpustakaan sebagai lembaga pengelola informasi sudah sejak lama menyadari pentingnya mengorganisasi informasi supaya bisa dimanfaatkan oleh penggunanya dengan efektif baik untuk sarana rekreasi, pendidikan maupun untuk memenuhi kebutuhan informasi lainnya. ${ }^{1}$ Organisasi informasi memungkinkan koleksi yang dimiliki oleh perpustakaan bisa diakses dengan mudah oleh pengguna sehingga akan membantu pengguna dalam memberikan pilihan koleksi yang diinginkan. Untuk mengakses informasi di perpustakaan diperlukan sarana temu kembali (retrieval tools). Katalog adalah sarana temu kembali yang telah lama digunakan oleh pemustaka untuk menemukan koleksi di perpustakaan karena sebagaimana yang dinyatakan oleh Charles Ammi Cutter pada awal tahun 1876 bahwa katalog memiliki fungsi penting yaitu: 1) memungkinkan pengguna menemukan dokumen yang sudah diketahui pengarang, judul atau subyeknya 2) menunjukkan apa yang dimiliki oleh perpustakaan tentang buku yang ditulis oleh pengarang tertentu,

\footnotetext{
${ }^{1}$ Jennifer E. Rowley, Organizing Knowledge: An Introduction to Managing Access to Information Retrieval2nd Ed (Vermon: Ashgate Publishing, Ltd., 1992), 3.
} 
buku tentang subyek tertentu dan dalam bentuk tertentu 3) membantu pengguna memberikan pilihan dokumen berdasarkan edisinya maupun karakternya. ${ }^{2}$

Untuk itu perpustakaan harus memiliki katalog sebagai sarana temu kembali informasi yang saat inidikembangkan dalam bentuk elektronik atau disebut Online Public Access Catalogue (OPAC). OPAC mempunyai tiga fungsi penting sebagai database bibliografi di mana OPAC bertindak sebagai indeks bagi user untuk mencari informasi terutama buku dan sebagai portal yang menyediakan link ke data non bibliografi baik informasi yang berkaitan dengan pengguna seperti: informasi tentang tagihan keterlambatan, denda, maupun informasi tentang perpustakaan misalnya jam buka. ${ }^{3}$ Sebenarnya OPAC sudah digunakan di perpustakaan sejak akhir 1970-an akan tetapi baru dikenal pada tahun 1980an. ${ }^{4}$ Dengan berbagai masa perkembangannya selama beberapa dekade, OPAC mengalami evolusi yang signifikan pada tahun 1990an. Pada masa ini sistem pada OPAC memiliki interface yang user-friendly (ramah pengguna) serta kapabilitas yang memadai seperti kemampuan untuk melakukan pencarian baik sederhana maupun pencarian kompleks. Bahkan pada tahun 2000an OPAC didesain dengan penambahan fasilitas yang lebih komunikatif sehingga pengguna perpustakaan bisa mendapatkan informasi yang lebih lengkap bahkan link ke sumber informasinya. Dan dengan adanya OPAC berbasis web ini memungkinkan masyarakat dari berbagai penjuru dunia bisa mengakses koleksi perpustakaan bahkan bisa berinteraksi dengan perpustakaan sehingga keberadaan OPAC ini sangat penting bagi perpustakaan, terutama perpustakaan perguruan tinggi. Oleh karena itu banyak perpustakaan perguruan tinggi di negara-negara maju yang kemudian mengembangkan software otomasi perpustakaan untuk OPAC seperti MELVYL (University of California), Cheshire II (at UC Berkeley) dan lainlainnya.

Perkembangan OPAC di perpustakaan perguruan tinggi menjadi sebuah tuntutan seiring dengan perkembangan teknologi informasi. Akan tetapi tidak

\footnotetext{
${ }^{2}$ Rowley, 16.

${ }^{3}$ David Wells, "What Is a Library OPAC?," The Electronic Library 25, no. 4 (2007): 3.

${ }^{4}$ Andrew Large, Lucy A. Tedd, and R. J. Hartley, Digital Libraries: Principles and Practice in a Global Environment (Munchen: K.G. Saur, 2005).
} 
semua OPAC bisa memenuhi gambaran ideal OPAC seperti penelitian yang dilakukan oleh Margam Madhusudhan dan Shalini Aggarwal di beberapa universitas di India yang menemukan bahwa hampir semua OPAC yang diteliti tidak memiliki federated search, adjunct thesaurus help dan fasilitas spell check, yang memunculkan pertanyaan yang berkaitan dengan fasilitas yang disediakan dalam OPAC 2.0 yang saat ini banyak digunakan. ${ }^{5}$

Perkembangan OPAC juga berkembang di perpustakaan Perguruan Tinggi di Indonesia. Bahkan sudah banyak dikembangkan software otomasi perpustakaan seperti INSIS, SIPRUS dan software berbasis open source yang saat ini sedang dikembangkan yaitu SLiMS. Perguruan Tinggi Negeri Islam di Indonesia juga sudah banyak mengembangkan perpustakaan yang berbasis otomasi yang kemudian juga mengaplikasikan OPAC berbasis web dengan menggunakan beragam software seperti SLiMS, LONTAR dan SIPRUS, terutama Univeritas Islam Negeri (UIN). UIN yang memiliki program studi umum (non-Studi KeIslaman) dituntut untuk bisa mensejajarkan diri dengan Pergurun Tinggi Umum lainnya, dan perpustakaan menjadi salah satu elemen penting dalam menentukan bagus tidaknya sebuah perguruan tinggi. Oleh karena itu UIN di Indonesia banyak melakukan pembenahan diri di bidang perpustakaan baik melalui sumber daya manusianya maupun dengan sumber daya lainnya misalnya perpustakaan dengan pengembangan OPAC-nya.

Pengembangan otomasi perpustakaan yang dikembangkan oleh perpustakaan Universitas Islam Negeri di Indonesia diharapkan mampu memberikan kemudahan akses layanan dan koleksi perpustakaan. Oleh karena itu perlu dikaji kelengkapan fasilitas searching dan browsing OPAC dan efektivitas fasilitas tersebut dalam proses temu kembali untuk membantu pemustaka menemukan informasi yang dibutuhkan.

\section{METODE PENELITIAN}

Penelitian ini menggunakan metode kombinasi sequential exploratory yaitu menggunakan metode kualitatif pada tahap awal dan dilanjutkan dengan

\footnotetext{
${ }^{5}$ Margam Madhusudhan and Shalini Aggarwal, "Web-Based Online Public Access Catalogues of IIT Libraries in India: An Evaluative Study," Program 45, no. 4 (2011): 415-38.
} 
metode kuantitatif pada tahap kedua. ${ }^{6}$ Dalam penelitian pada tahap pertama menggunakan data kualitatif yang bertujuan untuk mengidentifikasi ketersedian fasilitas yang ada di OPAC yang dilanjutkan dengan penggunaan metode kuantitatif untuk mengukur efektivitas OPAC sehingga akan diperoleh pengaruh fasilitas searching dan browsing terhadap efektivitas system temu kembali yang dalam hal ini diukur dengan nilai ketepatan (precision). Sampel diambil dengan menggunakan purposive sampling yaitu dengan memilih OPAC Perpustakaan Universitas Islam Negeri yang menggunakan software yang berbeda. Dari 17 UIN, maka diambil lima OPAC yang menggunakan software yang berbeda yaitu:

1. UIN Ar-Raniry Aceh yang menggunakan software berbasis open source SLIMS

2. UIN Syarif Hidayatullah, Tangerang Selatan (Banten) yang menggunakan software Lontar

3. UIN Sumatera Utara yang menggunakan software pengembangan sendiri

4. UIN Sunan Gunung Djati Bandung software pengembangan sendiri

5. UIN Sunan Kalijaga, Yogyakarta (D.I. Yogyakarta) yang menggunakan software pengembangan sendiri

Data kualitatif digunakan menemukan kelengkapan fasilitas pencarian dan fasilitas browsing OPAC di masing-masing UIN yang mencakup:

\section{Tabel 1}

Elemen-Elemen Fasilitas Searching dan Browsing

\begin{tabular}{|c|c|c|}
\hline NO & KATEGORI & SUB KATEGORI \\
\hline 1 & $\begin{array}{l}\text { Fitur Menu } \\
\text { Pencarian }\end{array}$ & $\begin{array}{l}\text { 1. Ketersediaan menu penelusuran sederhana } \\
\text { dengan fasilitas untuk pencarian spesifik } \\
\text { 2. Ketersediaan menu penelusuran lanjutan } \\
\text { 3. Link ke penelusuran sederhana/ penelusuran } \\
\text { lanjutan } \\
\text { 4. Single point of entry } \\
\text { 5. Ketersediaan menu bantuan }\end{array}$ \\
\hline 2 & $\begin{array}{l}\text { Fasilitas strategi } \\
\text { Searching }\end{array}$ & $\begin{array}{l}\text { 6. Faceted navigation: ketersediaan ruas cari } \\
\text { (subyek, judul, pengarang,lokasi, jenis } \\
\text { bahan (material), tahun, dsb.) } \\
\text { 7. Boolean Operator (AND, OR, NOT) } \\
\text { 8. Proximity: fasilitas membaca frase }\end{array}$ \\
\hline
\end{tabular}

\footnotetext{
${ }^{6}$ Sugiyono, Metode Penelitian Kombinasi (Mixed Methods) (Bandung: Alfabeta, 2013), 412.
} 
Marwiyah, Labibah, Evaluasi Kapabilitas Dan Efektivitas Online Public ...

\begin{tabular}{|c|c|c|}
\hline & & $\begin{array}{l}\text { 9. Term masking } \\
\text { 10. Numeric and data ranges } \\
\text { 11. Concept/ thesaurus expansion } \\
\text { 12. Query bahasa alamiah } \\
\text { 13. Search history log } \\
\text { 14. Canned/stores query }\end{array}$ \\
\hline 3 & Fasilitas browsing & $\begin{array}{l}\text { 15. Ranking } \\
\text { 16. Kelengkapan deskripsi bibliografi } \\
\text { 17. Display hasil pencarian: zoning dan } \\
\text { alternative tampilan hasil pencarian } \\
\text { (briefrecord dan fullrecord) } \\
\text { 18. Highlighting } \\
\text { 19. Enriched content: ketersediaan daftar isi, } \\
\text { summary dan gambar cover buku }\end{array}$ \\
\hline 4 & Fasilitas tambahan & $\begin{array}{l}\text { 20. Rekomendasi dan bahan-bahan terkait } \\
\text { 21. Kontribusi user dalam rating, review, } \\
\text { memberikan komentar dan tagging } \\
\text { 22. } R S S \text { feed }\end{array}$ \\
\hline
\end{tabular}

Pada tahap berikutnya, peneliti akan mengukur efektivitas OPAC dengan menggunakan beberapa kata cari yang diambil dari bidang Pendidikan dengan asumsi bahwa seluruh UIN yang menjadi sampel memiliki fakultas tarbiyah. Adapun kata cari yang digunakan sebagai sampel dalam penelitian ini adalah:

1. Pendidikan Anak Usia Dini

2. Sejarah Kebudayaan Islam

3. Sastra Arab

4. Fikih Wanita

5. Manajemen Dakwah

6. Sejarah Filsafat Islam

Kata kunci tersebut selanjutnya digunakan untuk melakukan searching dengan menggunakan fasilitas yang dimiliki oleh OPAC Perpustakaan UIN dan kemudian akan dihitung ketepatan hasilnya dengan menggunakan rumus precision. Dan untuk mengukur nilai ketepatan OPAC peneliti menggunakan rumus:

Item relevan yang ditemu kembali

Precision $=$ X $100 \%$

Jumlah total item yang ditemu kembali 


\section{KAJIAN TEORI}

\section{Sistem Temu Kembali Informasi}

Istilah temu kembali informasi muncul pada tahun 1952 dan mencapai kepopulerannya dalam masyarakat ilmiah mulai tahun $1961 .^{7}$ Pada masa ini fungsi organisasi temu kembali informasi dianggap sebagai kemajuan utama perpustakaan di mana perpustakaan bukan hanya sebagai tempat penyimpanan buku saja tetapi juga sebagai tempat di mana informasi dikatalog diindeks sehingga mudah ditemu kembali oleh user yang membutuhkan informasi tersebut.Oleh karena itu, di perpustakaan katalog menjadi bagian penting yang membantu temu kembali informasi. Katalog adalah file bibliografis yang berisi bibliographic record dan memberikan informasi tentang pengarang, judul,deskripsi fisik subyek dan jumlah cantuman. ${ }^{8}$ Dan dengan perkembangan teknologi informasi maka mulai katalog muncul dalam bentuk online yang kemudian dikenal dengan OPAC.Pada generasi di mana OPAC sudah menggunakan teknologi informasi, sistem temu kembali di perpustakaan lebih dikembangkan lagi dengan menambahkan beberapa fasilitas lagi seperti interface grafis, bentuk elektronik, fitur hypertext dan open system architectures.Bahkan vendor juga mulai mengembangkan sistem berdasarkan pada hasil riset yang kemudian dikembangkan di perpustakaan perguruan tinggi seperti Okapi (City University, London), MELVYL (University of California), dan Cheshire II di UC Berkeley. ${ }^{9}$

\section{Kapabilitas Sistem Temu kembali Informasi}

Menurut Kowalskysebuah sistem temu kembali informasi akan berfungsi dengan baik jika memiliki kapabilitas searching dan browsing karena kedua kapabilitas tersebut akan membantu user dalam menemukan dokumen yang relevan dengan kebutuhan informasinya. ${ }^{10}$ Hal senada juga disampaikan oleh

\footnotetext{
${ }^{7}$ G.G Chowdhury, Introduction to Modern Information Retrieval (London: Facet, 2004), 2.

${ }^{8}$ Hope A. Olson and John J. Boll, Subject Analysis in Online Catalogues 2nd Ed. (Englewood: Libraries Unlimited, 2001), 5.

${ }^{9}$ Ricardo Baeza-Yates and Berthier Ribeiro-Neto, Modern Information Retrieval (Essex: ACM Press, 2004), 7.

${ }^{10}$ Gerald J. Kowalski, Mark T. Maybury, and Mark T, Information Storage and Retrieval Systems (New York: Kluwer Academic Publisher, 2002), 28.
} 
Chowdury, bahwa ada dua moda akses informasi yang sangat mendasar dalam perpustakaan digital yaitu browsing dan searching. ${ }^{11}$ Dan sebagian besar sistem temu kembali informasi akan menyediakan fasilitas tersebut.Oleh karena itu visualisasi dan interface yang didesain dalam sistem temu kembali informasi akan membantu user dalam menggunakan sistem temu kembali tersebut.

Kapabilitas searching (penelusuran) memungkinkan adanya mapping antara kebutuhan user dengan dokumen yang disimpan dalam sistem temu kembali. Biasanya semua sistem temu kembali informasi memiliki paling tidak dua interface penelusuran yaitu penelusuran sederhana (yang biasanya didesain terutama untuk noviceuser) atau quick search dan penelusuran lanjut (advancedsearch) yang biasanya digunakan untuk user yang sudah berpengalaman. Advancedsearch ini juga digunakan untuk penelusuran yang sifatnya kompleks. Oleh karena itu desain pada advanced ini lebih kompleks dan menyediakan beberapa fasilitas misalnya batasan tahun. Selain itu, menurut Kowlasky, sistem temu kembali harus memiliki fasilitas-fasilitas searching seperti:

\section{Logika Boolean}

Fasilitas ini memungkinkan user untuk melakukan searching dengan menggunakan dua kata (konsep) atau lebih yang kemudian dihubungkan dengan tiga fungsi Boolean yaitu AND, OR dan NOT. Operasi AND digunakan untuk mempersempit hasil carian karena AND akan membuat kata cari yang digunakan akan muncul di dokumen yang dicari. OR akan membuat kata cari akan muncul, baik muncul sendiri maupun bersama dengan kata lain. Fungsi OR ini akanmemperluas hasil cari. Sedangkan fungsi NOT adalah untuk menghilangkan kata yang tidak diinginkan muncul dalam hasil pencarian.

\section{Proximity}

Word proximity adalah fasilitas yang memungkinkan user untuk membuat dua kata cari yang dicari dibaca oleh sistem sebagai frase.Proximity juga memungkinkan user untuk mengatur susunan kata cari supaya menghasilkan hasil yang spesifik. Word proximity yang paling umum digunakan di system temu

\footnotetext{
${ }^{11}$ Chowdhury, Introduction to Modern Information Retrieval, 232.
} 
kembali informasi adalah dengan memberikan tanda kutip (“...”), misal "perpustakaan sekolah" supaya konsep tersebut dibaca sebagai frase. Kadang juga merujuk pada letak/posisi duaterm (sebelum atau sesudah) yang sering disebut dengan adjacency

\section{Fuzzy search}

Yaitu kemampuan untuk menemukan ejaan kata yang mirip dengan kata yang dimasukkan dalam istilah cari.Fuzzy search berfungsi untuk membantu dalam kesalahan menulis. Dalam proses perluasan istilah cari fuzzysearchakan mencari semua kata yang mirip, melakukan weighting terhadap istilah cari dalam database yang memiliki panjang kata yang sama dan posisi karakter dengan istilah cari. Fuzzy search akan bekerja dengan maksimal dalam sistem yang memiliki OCR (Optical Character Read). Fuzzy search memungkinkan lokasi item yang mengakomodir karakter (huruf) yang salah

4. Term masking

Fasilitas ini memungkinkan user untuk memperluas istilah cari dengan menyisipkan simbol untuk me-masking sebagian dari istilah cari tersebut dan akan menganggap setiap kata yang yang bersinggungan dengan istilah yang di-masking sebagai hasil yang harus dimunculkan. Ada tiga cara penggunaan terma masking yaitu:

1. Suffix search $\rightarrow *$ computer

2. Prefix search $\rightarrow$ computer*

3. Imbedded string search $\rightarrow *$ computer*

Masing-masing sistem temu kembali mungkin bereda dalam menggunakan term masking ini, akan tetapi biasanya paling tidak mempunyai prefix search yang sering disebut dengan truncation, yang biasanya digunakan ketika user tidak tahu ejaan di bagian akhir kata kunci. Truncationakan mencarikan informasi yang mempunyai stemword (akar kata/kata dasar) yang sama dengan yang ditulis oleh user.

5. Numeric and data ranges

Fasilitas ini memungkinkan user untuk mencari informasi dengan batasan tahun yang diinginkan oleh user, atau batasan data. 
Marwiyah, Labibah, Evaluasi Kapabilitas Dan Efektivitas Online Public ...

\section{Concept/thesaurus expansion}

Kemampuan memperluas istilah cari melalui thesaurus atau kelas konsep, sarana referensi database. Merupakan perluasan dari satu istilah cari ke istilah lain yang dari segi makna saling berkaitan. Fasilitas ini membantu user yang memiliki keterbatasan pengetahuan istilah atau bahkan subyek tertentu dengan menunjukkan serangkaian istilah yang mungkin berkaitan.

7. Query bahasa alamiah (natural language query)

Memungkinkan user untuk menggunakan kata cari sesuai yang diinginkan untuk menemukan informasi yang dibutuhkan. Asumsinya, semakin panjang kata cari yang digunakan semakin akurat atau spesifik hasil yang diperoleh

8. Multimedia query yaitu fasilitas untuk mencari koleksi dalam bentuk multimedia atau menyediakan pencarian seperti audio dan video.

Dan untuk sistem temu kembali informasi di perpustakaan yang dalam hal ini adalah OPAC maka tidak semua fasilitas tersebut di atas sesuai, misalnya saja untuk contagious word phrases dan fuzzy logic yang akan memberikan hasil carian (recall) yang tinggi akan tetapi memiliki nilai ketepatan yang rendah. Fasilitas yang paling penting dimiliki oleh OPAC adalah logika Boolean, proximity, termmasking, concept/thesaurus expansion dan Bahasa alamiah (natural language).

Selain memiliki fasilitas searching, sebuah sistem temu kembali juga harus mempunyai kapabilitas browsing. Setelah proses searching selesai, kapabilitas browsing akan menyediakan fasilitas untuk menentukan dokumen mana sesuai dengan kebutuhan mereka dan memilih dokumen dengan melalui hasil carian yang di-display. Ada dua jenis display ringkasan dokumen yang berkaitan dengan query yaitu line item status dan visualisasi. ${ }^{12}$ Dari ringkasan dokumen ini user bisa memilih dokumen yang spesifik dan daerah (zona) dalam dokumen tersebut. Kapabilitas browsing ini akan membantu user dalam memfokuskan dokumen relevan yang dicari. Kapabilitas browsing yang harus dimiliki oleh sistem temu kembali informasi adalah:

${ }^{12}$ Kowalski, Maybury, and T, Information Storage and Retrieval Systems, 38. 
a. Ranking yaitu display hasil temu kembali (hit) yang diurutkan berdasarkan kriteria tertentu misal waktu dan relevansinya.

b. Zoning, yaitu display hasil temu kembali berdasarkan zona/daerah yang ditentukan oleh user misalnya display berdasarkan abstrak dan judul. Termasuk di sini kelengkapan deskripsi bibliografi sesuai dengan standard InternationalStandardofBookDescription (ISBD) dan pilihan untuk melihat hasil pencarian yaitu singkat (brief record) dan lengkap (full record).

c. Highlighting yaitu display hasil temu kembali informasi dimana kata kunci digunakan user ketika mencari di-highlight kata kunci sehingga user tahu relevansi hasil yang sedang dicari.

Menurut Kowalsky, sistem temu kembali juga perlu memiliki fasilitas tambahan yang bisa membantu user untuk melakukan Input Querydengan tepat. ${ }^{13}$ Oleh karena itu, menurut Kowalsky ada tiga fungsi yang bisa ditambahkanyaitu:

a. Vocabulary Browse(melihat-lihat kosakata) yaitu kemampuan untuk mendisplay kata-kata dalam database dokumen dalam susunan abjad

b. Iterative Searchand Search History Logyaitu penyimpanan kata cari yang sudah digunakan untuk searching

c. Canned/ Stored Queryyaitu kemampuan untuk menulis querydan menyimpannya untuk ditemukembali lain waktu.

Dalam perkembangan OPAC, ada beberapa penambahan beberapa fitur yang dikembangkan untuk meningkatkan kinerja OPAC seperti yang dikembangkan Breeding dalam laporannya yang berjudul "Next-Generation Library Catalogs" yang menganjurkan fitur tambahan. ${ }^{14}$ Adapun fitur tambahan tersebut yaitu:

a. A single point of entry to all library information yaitu informasi merujuk pada semua jenis sumber perpustakaan (library resources) seperti jurnal, video, full text semua database elektronik, arsip digital dan sumber perpustakaan lainnya.

\footnotetext{
${ }_{14}^{13}$ Kowalski, Maybury, and T, 41-45.

${ }^{14}$ Marshall Breeding, "Introduction to "The next Generation Library Catalog," Library Technology Reports 43, no. 4 (2007): 5-14.
} 
Marwiyah, Labibah, Evaluasi Kapabilitas Dan Efektivitas Online Public ...

b. Nilai seni pada interface (State-of-the-art Web interface). OPAC sebaiknya dilengkapi dengan interface yang alami dan menjadi tempat yang menarik untuk dikunjungi.

c. Enriched content. Tampilan katalog tidak hanya deskripsi bibliografis dalam berbagai format saja akan tetapi juga dilengkapi informasi yang mungkin berguna bagi user seperti gambar sampul buku, daftar isi dan summary.

d. Faceted navigation yaitu fasilitas yang memungkinkan user mempersempit hasil searching dengan membatasi carian pada ruas cari yaitu: subjects, authors, dates, typesofmaterials, locations, series, andmore.

e. Simple keyword search box. OPAC sebaiknya menyediakan fasilitas pencarian sederhana tetapi memungkinkan user melakukan pencarian yang spesifik seperti pada interface Google. Selain itu, pada menu pencarian sederhana ini juga disediakan link untuk melakukan pencarian advanced.

f. Relevancy yang berkaitan dengan ranking tidak hanya didasarkan pada frekuensi dan posisi kata cari dalam cantuman bibliografis dalam pencarian berdasarkan kata kunci tetapi juga kriteria lain seperti seringnya dipinjam

g. Spell-checker dalam fitur "Did you mean... ?" yang merupakan pertanyaan untukmengonfirmasi apakah kata cari yang diketik sudah benar.

h. Recommendations and related materials. Katalog next-generation sebaiknya juga bertindak sebagai sarana promosi sehingga menyediakan bacaan yang berkaitan dengan bacaan lain yang sejenis. Biasanya yang memiliki fasilitas ini adalah database jurnal elektronik yang memberikan daftar judul dengan kajian sejenis. Dalam OPAC jarang digunakan fasilitas ini, akan tetapi keberadaan tajuk subjek dalam ruas subjek bisa berfungsi sebagai rekomendasi kepada user yang akan mencari dengan subyek yang sejenis.

i. Kontribusi user dalammelakukan rating, review, memberikan komentar dan tagging. Kontribusi ini merupakan indikator penting untuk digunakan sebagai ranking relevansi, terutama jika dilakukan oleh user yang sudah mahir dalam melakukan searching.

j. $\quad$ RSS feeds. OPAC menyediakan update dan menyediakan daftar buku baru melalui RSS feeds. 


\section{Evaluasi Sistem Temu Kembali Informasi}

Sebuah sistem temu kembali yang sudah dikembangkan perlu dievaluasi untuk mengetahui tingkat performance sistem tersebut. Menurut Lancaster dalam Chowdury sistem temu kembali informasi perlu dievaluasi karena tiga alasan berikut: ${ }^{15}$

1. Untuk mengetahui seberapa bagus sistem bisa memenuhi tujuan dikembangkannya sistem temu kembali informasi

2. Seberapa efisien sistem tersebut

3. Apakah sistem tersebut sudah bagus

Dan untuk melakukan evaluasi diperlukan kriteria pengukuran evaluasi.Beberapa ahli di bidang informasi memberikan beberapa kriteria. Yang pertama adalah Cleverdon yang menyatakan bahwa evaluasi yang berorientasi pengguna seharusnya bisa menjawab pertanyaan-pertanyaan berikut:

1. Seberapa besar sistem bisa memenuhi kebutuhan masyarakat penggunanya

2. Apa yang menyebabkan sistem tersebut tidak bisa memenuhi kebutuhan penggunanya

3. Bagaimana tingkat cost-effectiveness penelusurannya

4. Perubahan mendasar apa yang harus dilakukan untuk meningkatkan hasil penelusuran

Kriteria evaluasi system temu kembali informasi terus dikembangkan oleh beberapa ahli seperti Lancaster yang kemudian mengembangkan lima kriteria evaluasi yang lebih rinci yaitu: ${ }^{16}$

1. cakupan sistem,

2. kemampuan untuk hanya menemu kembali dokumen-dokumen yang diinginkan (recall)

3. kemampuan sistem untuk menghindari terjaringnya dokumen-dokumen yang tidak relavan (precision)

4. waktu respon sistem dalam menemu kembali dokumen yang dicari pengguna

5. beban kerja (usereffort) yang dialami user dalam mencari dokumen

${ }^{15}$ Chowdhury, Introduction to Modern Information Retrieval, 243.

${ }^{16}$ Chowdhury, 246. 
Marwiyah, Labibah, Evaluasi Kapabilitas Dan Efektivitas Online Public ...

Faktor-faktor yang dikemukakan oleh Cleverdon dan Lancaster tersebut di atas akan mempengaruhi kinerja sistem temu kembali informasi. Selain itu, kinerja sistem temu kembali informasi juga dipengaruhi tersedianya fasilitasfasilitas yang memungkinkan user untuk mencari informasi secara spesifik seperti tersedianya boolean operator AND dan NOT yang akan membatasi penelusuran yang lebih spesifik sehingga bisa meningkatkan nilai ketepatan (precision) sistem temu kembali informasi.

Dari berbagai penelitian sistem temu kembali informasi yang telah dilakukan, fokus penelitian ada dua jenis yaitu:1) penelitian dari sisi manajerial yang mudah untuk diukur misalnya cakupan koleksi, dan 2) efektivitas sistem temu kembali yaitu dengan melihat nilai ketepatannya (precision) dan perolehan (recall) yang lebih sulit untuk diukur. Dan yang akan menjadi salah satu fokus dalam penelitian ini adalah ukuran efektivitas dengan fokus pada precision yang menitikberatkan pada nilai ketepatan hasil carian yang dalam hal ini akan dipengaruhi oleh banyak faktor seperti sistem pengindeksan yang digunakan oleh system temu kembali tersebut yang berkaitan dengan Bahasa penelusuran dan ketersediaan fasilitas pencarian (searching) yang memungkinkan user melakukan pencarian spesifik. Kunci penting dariprecision adalah pengukuran terhadap hasil penelusuran yang relevan. Relevan menurut Large merupakan judgment yang didasarkan pada match antara subject content (aboutness) dari record yang ditemukan dengan query yang digunakan oleh user dalam penelusuran. ${ }^{17}$

\section{HASIL PENELITIAN DAN PEMBAHASAN}

\section{Kelengkapan Fasilitas}

OPAC yang dikembangkan di perpustakaan Universitas Islam Negeri menggunakan beragam software baik menggunakan open source (missal SLiMS) dengan berbagai platform (akasia, cendana, dan lainnya), software berbayar yang kemudian dimodifikasi sesuai dengan kebutuhan perpustakaan (Lontar) dan software yang dikembangkan sendiri. Masing-masing OPAC memiliki fitur yang beragam dan dari hasil pengamatan terhadap fasilitas pencarian yang peneliti

\footnotetext{
17 Andrew Large, Lucy A. Tedd, and R. J. Hartley, Seeking in the Online Age: Principles and Practice (Munchen: KG Saur, 2001), 285.
} 
lakukan, ditemukan beberapa karakteristik dari OPAC yang dikembangkan di UIN ini.

1. Fitur Menu Pencarian

Pada dasarnya menu pencarian merupakan tempat pertama di mana pemustaka berhadapan dengan system temu kembali sehingga desain dan fitur pada menu ini akan mempengaruhi proses pencarian. Berdasarkan hasil observasi pada OPAC lima UIN yang diteliti menu pencarian OPAC memiliki desain sederhana. Bahkan pada OPAC UIN Ar Raniry, UIN Sunan Gunungdjati dan UIN Sunan Kalijagai hanya memiliki menu pencarian sederhana saja, yang hanya terdiri dari satu menu kotak pencarian (search box) tanpa dilengkapi dengan menu penelusuran lanjutan/advanced). Sedangkan UIN Syarif Hidayatullah dan UIN Sumatera Utara memiliki memiliki dua menu pencarian tersebut (sederhana dan lanjutan).

\section{Gambar 1}

Tampilan Menu Pencarian Sederhana

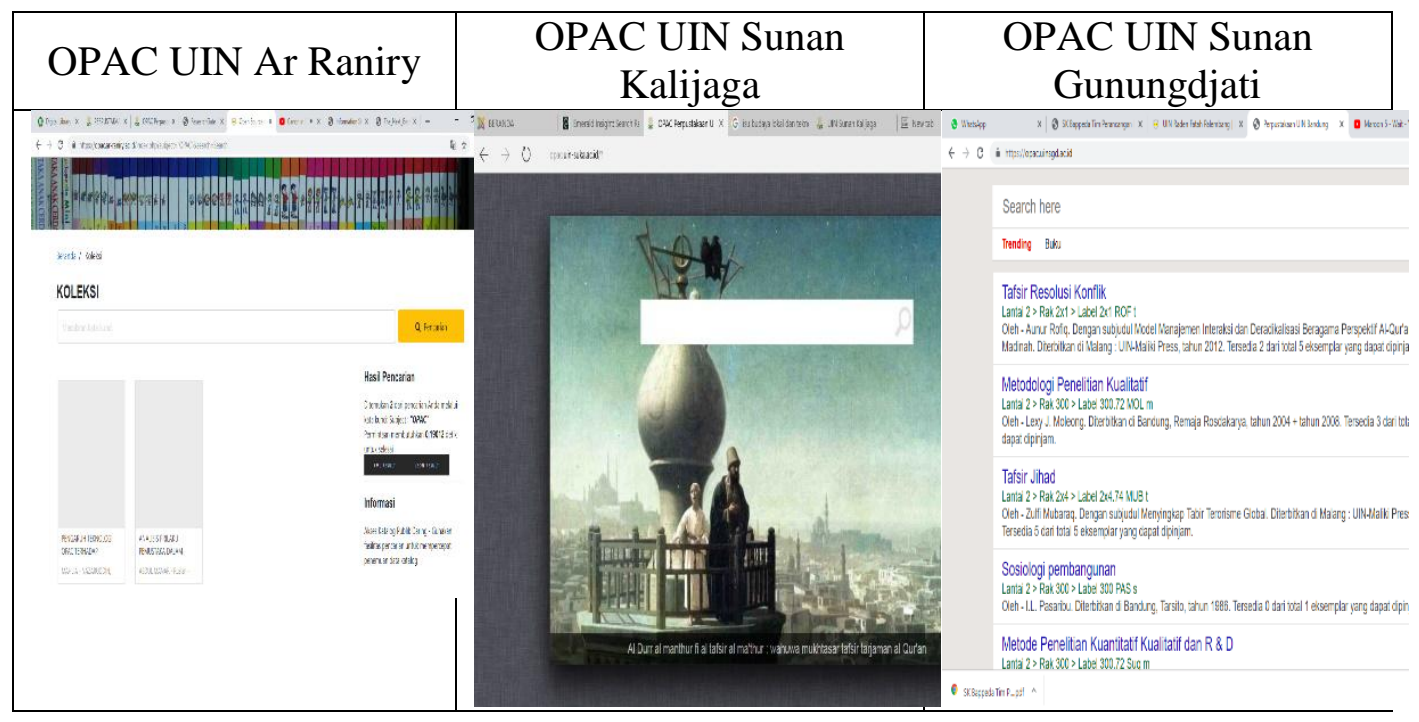

Fasilitas pencarian yang tersedia dalam menu pencarian sangat mempengaruhi kemampuan untuk melakukan pencarian yang spesifik. Meskipun fitur menu pencarian yang dimiliki lima OPAC UIN hanya sederhana akan tetapi bisa digunakan untuk melakukan pencarian spesifik. OPAC UIN Syarif Hidayatullah yang memiliki fasilitas lengkap terutama pada pencarian advanced 
memungkinkan untuk melakukan pencarian spesifik. Menu pencarian sederhana juga bisa digunakan untuk pencarian spesifik jika dilengkapi fasilitas pencarian seperti pembatasan pencarian pada kategori tertentu seperti pada OPAC UIN Ar Raniry yang menyediakan pilihan ruas cari. Sedangkan pada OPAC UIN Sunan Kalijagai meskipun hanya memiliki menu pencarian sederhana, akan tetapi juga tersedia fasilitas modifikasi pencarian yang memungkinkan membatasi pencarian dengan kategori tertentu yaitu pencarian frase, pencarian pada ruas cari tertentu dan booelan operator. Oleh karena itu meskipun menu pencarian sederhana akan tetapi OPAC UIN menyediakan fasilitas pencarian spesifik.

Salah satu karakteristik sistem temu kembali informasi yang dikembangkan saat ini adalah tersedianyasingle point of entryyang memungkinkan pemustaka bisa mencari berbagai jenis dokumen dalam berbagai jenis dan format (artikel, jurnal, buku, dan lainnya) dalam satu kotak pencarian.OPAC yang dikembangkan oleh 5 UIN belum menerapkan single point of entry. Sebenarnya perpustakaan di lima UIN memiliki koleksi berupa artikel, laporan penelitian ataupun skripsi/ thesis di database lain terpisah yaitu di repository. Akan tetapi repository ini belum terhubungkan dalam OPAC sehingga pencarian harus dilakukan pada masing-masing database dan menu pencarian, kecuali skripsi/thesis seperti yang bisa diakses melalui OPAC. Di lima OPAC UIN ini, pemustaka masih bisa melakukan pencarian skripsi dan buku di OPAC.

Salah satu kelengkapan system temu kembali informasi adalah tersedianya menu bantuan penelusuran sehingga akan memudahkan pemustaka dalam mencari informasi. Dan ini adalah kekurangan dari lima OPAC UIN. Pada kelima OPAC tersebut tidak tersedia menu bantuan pencarian sehingga fasilitas pencarian yang lengkap tidak diketahui oleh pemustaka, kecuali pemustaka yang sudah berpengalaman. Dari lima OPAC UIN yang diteliti, hanya OPAC UIN Syarif Hidayatullah yang menyediakan menu bantuan yang memandu pemustaka dalam menggunakan OPAC. Pada dasarnya OPAC UIN memang didesain dengan menu yang sederhana sehingga bisa diasumsikan bahwa OPAC tersebut mudah digunakan dan tidak diperlukan menu bantuan, misalnya saja OPAC UIN Sunan Gunungdjati. Tampilan OPAC ini memang sangat sederhana sehingga tanpa 
adanya menu bantuan tidak akanmemberikan dampak yang besar karena memang tidak memiliki banyak fasilitas pencarian. Akan tetapi desain menu sederhana pada OPAC ini bukan berarti tidak penting untuk menyediakan menu bantuan, bahkan pemustaka perlu mengetahui fasilitas dasar seperti pencarian menggunakan frase yang biasanya ditunjang dengan fasilitas tanda kutip. Begitu juga dengan OPAC UIN Sunan Kalijaga yang tidak dilengkapi menu bantuan pencarian, padahal, meskipun desain OPAC yang hanya memiliki menu pencarian sederhana, akan tetapi pada menu hasil pencarian, terdapat fasilitas refine search melalui menu setting yang memungkinkan untuk melakukan pembatasan ke pencarian yang lebih spesifik. Akan tetapi dengan tidak tersedianya menu bantuan, maka pengguna OPAC tidak bisa melakukan pencarian spesifik, terutama bagi pencari informasi yang masih pemula. Dengan begitu, ketersediaan menu bantuan yang ditampilkan dengan jelas akan sangat membantu pemustaka. Dari beberapa unsur fitur meu pencarian OPAC, fitur pencarian pada lima OPAC UIN adalah sebagai berikut:

Tabel 2

Fitur Menu Pencarian yang dimiliki 5 UIN

\begin{tabular}{|l|c|c|c|c|c|}
\hline Kategori & $\begin{array}{c}\text { UIN Ar } \\
\text { Raniry }\end{array}$ & $\begin{array}{c}\text { UIN Syarif } \\
\text { Hidayatullah }\end{array}$ & $\begin{array}{c}\text { UIN } \\
\text { Sumatera } \\
\text { Utara }\end{array}$ & $\begin{array}{c}\text { UIN } \\
\text { Bandung }\end{array}$ & $\begin{array}{c}\text { UIN } \\
\text { Sunan } \\
\text { Kalijagai }\end{array}$ \\
\hline $\begin{array}{l}\text { Menu } \\
\text { sederhana }\end{array}$ & Ada & Ada & Ada & Ada & Ada \\
\hline $\begin{array}{l}\text { Menu } \\
\text { lanjutan }\end{array}$ & $\begin{array}{c}\text { Tidak } \\
\text { Ada }\end{array}$ & Ada & Ada & Tidak Ada & $\begin{array}{c}\text { Tidak } \\
\text { Ada }\end{array}$ \\
\hline $\begin{array}{l}\text { Link ke } \\
\text { menu } \\
\text { lanjutan }\end{array}$ & $\begin{array}{c}\text { Tidak } \\
\text { Ada }\end{array}$ & Ada & Ada & Tidak Ada & $\begin{array}{c}\text { Tidak } \\
\text { Ada }\end{array}$ \\
\hline $\begin{array}{l}\text { Single } \\
\text { point of } \\
\text { entry }\end{array}$ & $\begin{array}{c}\text { Tidak } \\
\text { Ada }\end{array}$ & Ada & Ada & Tidak Ada & $\begin{array}{c}\text { Tidak } \\
\text { Ada }\end{array}$ \\
\hline $\begin{array}{l}\text { Menu } \\
\text { bantuan }\end{array}$ & $\begin{array}{c}\text { Tidak } \\
\text { Ada }\end{array}$ & Ada & Tidak Ada & Tidak Ada & $\begin{array}{c}\text { Tidak } \\
\text { Ada }\end{array}$ \\
\hline
\end{tabular}


Marwiyah, Labibah, Evaluasi Kapabilitas Dan Efektivitas Online Public ...

\section{Fasilitas Pencarian}

Fasilitas pencarian akan membantu dalam pencarian spesifik sehingga keberadaan fasilitas ini sangat penting. Akan tetapi pada OPAC UIN tidak semua memiliki fasilitas pencarian yang ideal. OPAC yang dilengkapi dengan pilihan kategori pencarian pada ruas cari (seperti ruas judul, pengarang, subyek, dan lainnya) akan memungkinkan pengguna melakukan pencarian yang lebih spesifik, seperti pencarian tentang subyek tertentu. OPAC yang memiliki fasilitas ini adalah OPAC UIN Syarif Hidayatullah dan Sumatera Utara. Akan tetapi pada UIN Sumatera Utara pilihan ini terbatas yaitu hanya pada obyek cari berupa pilihan buku dan jenis lainnya dan judul pada pencarian sederhana dan pilihan tambahan yaitu pengarang, subyek, penerbit pada pencarian advanced. Kategorkategori pada ruas pencarian ini bersifat fixed, di mana setiap ruas, satu kategori tidak bisa diubah ke kategori lainnya. Hal ini berbeda dengan OPAC UIN Syarif Hidayatullah di mana dalam satu ruas cari pemustaka bisa memilih kategori yang diinginkan yaitu judul, subyek maupun pengarang. Dengan memiliki beberapa kategori dan ruas cari, memungkinkan pemustaka untuk melakukan pencarian dengan faceted navigation misalnya saja pencarian pada subyek tertentu yang ditulis oleh pengarang tertentu dengan menggunakan Bahasa tertentu, maka akan memberikan hasil yang spesifik. Dengan kata lain pencarian dengan faceted navigation hanya bisa dilakukan di OPAC UIN Syarif Hidayatullah dan UIN Sumatera Utara.

\section{Gambar 2}

\section{OPAC UIN Syarif Hidayatullah}

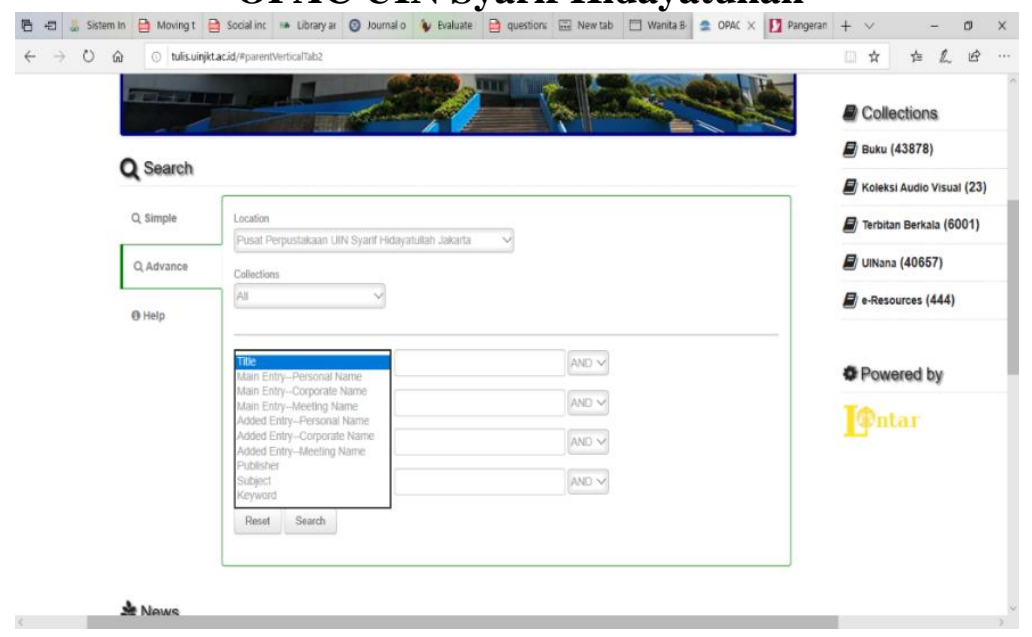


Pencarian spesifik juga bisa dilakukan jika OPAC memiliki fasilitas stratgei penelusuran yang memadai seperti Boolean operator, pencarian frase dan lain-lain.Tidak semua OPAC UIN memiliki fasilitas pencarian yang ideal. Misalnya saja untuk Boolean operator, yang memiliki dengan sempurna hanya UIN Syarif Hidayatullah yaitu pada menu pencarian advanced di mana antar ruas cari dihubungkan dengan operator AND, OR dan NOT yang bisa dipilih oleh pemustaka. Di OPAC UIN lainnya tidak memiliki operator ini, meskipun ada fasilitas penggabungan antar ruas cari akan tetapi tidak ada pilihan Boolean operator sehingga antar ruas tersebut otomatis akan dianggap sebagai operator AND. Begitu juga dengan fasilitas pencarian lainnya yaitu numeric and data rangeatau pembatasan pencarian berdasarkan rentang tahun terbit dokumen yang tidak dimiliki oleh semua OPAC UIN.Hal ini menyebabkan hasil pencarian yang banyak, karena pemustaka tidak bisa membatasi batasan waktu atau tahun terbit.Untuk fasilitas proximity juga tidak semua OPAC UIN memilikinya.Fasilitas proximity yang minimal tersedia dalam bentuk pembatasan frase yaitu pencarian dengan menggunakan kata cari berupa frase. Fasilitas pencarian frase dengan menggunakan tanda kutip (“...”) diempat OPAC UIN yaitu UIN Syarif Hidayatullah, UIN Sunan Kalijaga, UIN Sumatera Utara dan UIN Ar Raniry Aceh. Sedang OPAC UIN Sunan Gunungdjati tidak memiliki fasilitas ini.Pencarian spesifik juga bisa dilakukan dengan membatasi hasil pencarian berdasarkan kriteria tertentu, misalnya tahun terbit dan Bahasa yang digunakan dalam dokumendan lokasi di mana koleksi tersebut disimpan, misalnya perpustakaan fakultas.Fasilitas pembatasan ini secara keseluruhan tidak dimiliki oleh OPAC UIN.Hanya perpustakaan UIN Syarif Hidayatullah yang memiliki fasilitas membatasi pada lokasi karena UIN Syarif Hidayatullah memiliki perpustakaan di tingkat fakultas. OPAC UIN Sumatera Utara juga memiliki pilihan lokasi perpustakaan akan tetapi yang bisa digunakan hanya Perpustakaan Pusat sehingga fasilitas ini tidak bisa digunakan. OPAC Perpustakaan UIN Sunan Kalijagai sebenarnya juga memiliki fasilitas pembatasan (limit atau narrow) yang berfungsi untuk mempersempit hasil pencarian, akan tetapi hanya bisa dilakukan setelah proses pencarian yaitu melalui penyaringan hasil pencarian, di mana 
Marwiyah, Labibah, Evaluasi Kapabilitas Dan Efektivitas Online Public ...

pengguna bisa membatasi hasil berdasarkan jenis dokumen, tahun terbit. Adapun ketersediaan fasilitas searching lima OPAC UIN bisa dilihat pada table di bawah ini:

Tabel 3

Fasilitas Searching yang dimiliki 5 UIN

\begin{tabular}{|c|c|c|c|c|c|c|}
\hline NO & Kategori & $\begin{array}{l}\text { UIN Ar } \\
\text { Raniry }\end{array}$ & $\begin{array}{l}\text { UIN Syarif } \\
\text { Hidayatullah }\end{array}$ & $\begin{array}{c}\text { UIN } \\
\text { Sumatera } \\
\text { Utara }\end{array}$ & $\begin{array}{c}\text { UIN } \\
\text { Bandung }\end{array}$ & $\begin{array}{c}\text { UIN } \\
\text { Sunan } \\
\text { Kalijaga }\end{array}$ \\
\hline 1 & \begin{tabular}{|l|} 
Faceted \\
navigation: \\
ketersediaan ruas \\
cari (subyek, \\
judul, pengarang, \\
lokasi, jenis \\
bahan (material), \\
tahun, dsb.)
\end{tabular} & $\begin{array}{l}\text { Tidak } \\
\text { ada }\end{array}$ & Ada & $\begin{array}{l}\text { Ada tapi } \\
\text { terbatas }\end{array}$ & $\begin{array}{l}\text { Tidak } \\
\text { ada }\end{array}$ & $\begin{array}{l}\text { Tidak } \\
\text { ada }\end{array}$ \\
\hline 2 & $\begin{array}{l}\text { Boolean } \\
\text { Operator (AND, } \\
\text { OR, NOT) }\end{array}$ & $\begin{array}{l}\text { Hanya } \\
\text { tersedia } \\
\text { Operator } \\
\text { AND }\end{array}$ & Ada & Tidak ada & $\begin{array}{l}\text { Tidak } \\
\text { ada }\end{array}$ & $\begin{array}{l}\text { Tidak } \\
\text { ada }\end{array}$ \\
\hline 3 & $\begin{array}{l}\text { Proximity: } \\
\text { fasilitas } \\
\text { membaca frase }\end{array}$ & Ada & Ada & Ada & $\begin{array}{l}\text { Tidak } \\
\text { ada }\end{array}$ & Ada \\
\hline 4 & Term masking & $\begin{array}{l}\text { Tidak } \\
\text { ada }\end{array}$ & $\begin{array}{l}\text { Ada, dalam } \\
\text { bentuk } \\
\text { Truncation }\end{array}$ & $\begin{array}{l}\text { Ada, } \\
\text { dalam } \\
\text { bentuk } \\
\text { Truncation }\end{array}$ & $\begin{array}{l}\text { Tidak } \\
\text { ada }\end{array}$ & $\begin{array}{l}\text { Tidak } \\
\text { ada }\end{array}$ \\
\hline 5 & $\begin{array}{l}\text { Numeric and } \\
\text { data ranges }\end{array}$ & $\begin{array}{l}\text { Tidak } \\
\text { ada }\end{array}$ & Tidak ada & Tidak ada & $\begin{array}{l}\text { Tidak } \\
\text { ada }\end{array}$ & $\begin{array}{l}\text { Tidak } \\
\text { ada }\end{array}$ \\
\hline 6 & \begin{tabular}{|l|} 
Concept/ \\
thesaurus \\
expansion
\end{tabular} & $\begin{array}{l}\text { Tidak } \\
\text { ada }\end{array}$ & Tidak ada & Tidak ada & $\begin{array}{l}\text { Tidak } \\
\text { ada }\end{array}$ & $\begin{array}{l}\text { Tidak } \\
\text { ada }\end{array}$ \\
\hline 7 & $\begin{array}{l}\text { Query bahasa } \\
\text { alamiah }\end{array}$ & Ada & Ada & Ada & Ada & Ada \\
\hline 8 & $\begin{array}{l}\text { Search history } \\
\log \end{array}$ & $\begin{array}{l}\text { Tidak } \\
\text { ada }\end{array}$ & $\begin{array}{ll}\text { Ada } & \text { tapi } \\
\text { terbatas }\end{array}$ & Tidak ada & $\begin{array}{l}\text { Tidak } \\
\text { ada }\end{array}$ & $\begin{array}{l}\text { Tidak } \\
\text { ada }\end{array}$ \\
\hline 9 & $\begin{array}{l}\text { Canned/stores } \\
\text { query }\end{array}$ & $\begin{array}{l}\text { Tidak } \\
\text { ada }\end{array}$ & $\begin{array}{l}\text { Bisa } \\
\text { menyimpan } \\
\text { pencarian } \\
\text { sementara }\end{array}$ & Tidak ada & $\begin{array}{l}\text { Tidak } \\
\text { ada }\end{array}$ & $\begin{array}{l}\text { Tidak } \\
\text { ada }\end{array}$ \\
\hline
\end{tabular}




\section{Fasilitas Browsing}

Fasilitas browsingmempunyai fungsi penting dalam proses seleksi hasil pencarian yaitu dalam menentukan apakah hasil yang ditemukan sesuai dengan kebutuhan informasi pengguna. Akan tetapi sepertinya fasilitas ini tidak menjadi pertimbangan penting dalam desain OPAC UIN di mana hanya memberikan beberapa fasilitas browsing bagi pengguna, seperti yang ditunjukkan pada table 4 di bawah ini.

\section{Tabel 4}

Fasilitas Browsing yang dimiliki 5 UIN

\begin{tabular}{|c|c|c|c|c|c|c|}
\hline No & Kategori & $\begin{array}{l}\text { UIN Ar } \\
\text { Raniry }\end{array}$ & $\begin{array}{l}\text { UIN Syarif } \\
\text { Hidayatullah }\end{array}$ & $\begin{array}{c}\text { UIN } \\
\text { Sumatera } \\
\text { Utara }\end{array}$ & $\begin{array}{c}\text { UIN } \\
\text { Bandung }\end{array}$ & $\begin{array}{c}\text { UIN } \\
\text { Sunan } \\
\text { Kalijaga }\end{array}$ \\
\hline 1 & Ranking & $\begin{array}{l}\text { Tidak } \\
\text { ada }\end{array}$ & Tidak ada & Tidak ada & Tidak ada & $\begin{array}{l}\text { Tidak } \\
\text { ada }\end{array}$ \\
\hline 2 & $\begin{array}{l}\text { Kelengkapa } \\
\mathrm{n} \text { deskripsi } \\
\text { bibliografi }\end{array}$ & $\begin{array}{l}\text { Sesuai } \\
\text { ISBD, } \\
\text { area } \\
\text { catatan } \\
\text { masih } \\
\text { terbatas }\end{array}$ & $\begin{array}{l}\text { Sesuai ISBD, } \\
\text { area catatan } \\
\text { masih terbatas }\end{array}$ & $\begin{array}{l}\text { Kurang } \\
\text { lengkap } \\
\text { (area } \\
\text { catatan dan } \\
\text { ISBN } \\
\text { belum ada) }\end{array}$ & $\begin{array}{l}\text { Kurang } \\
\text { lengkap } \\
\text { (tidak ada } \\
\text { area } \\
\text { catatan) }\end{array}$ & $\begin{array}{l}\text { Kurang } \\
\text { lengkap }\end{array}$ \\
\hline 3 & $\begin{array}{l}\text { Display hasil } \\
\text { pencarian: } \\
\text { zoning dan } \\
\text { alternative } \\
\text { tampilan } \\
\text { hasil } \\
\text { pencarian } \\
\text { (brief record } \\
\text { dan full } \\
\text { record) }\end{array}$ & $\begin{array}{l}\text { brief } \\
\text { dan full } \\
\text { record }\end{array}$ & $\begin{array}{l}\text { brief dan full } \\
\text { record }\end{array}$ & $\begin{array}{l}\text { brief dan } \\
\text { full record }\end{array}$ & $\begin{array}{l}\text { Hanya } \\
\text { brief } \\
\text { record }\end{array}$ & $\begin{array}{l}\text { Hanya } \\
\text { brief } \\
\text { record }\end{array}$ \\
\hline 4 & Highlighting & $\begin{array}{l}\text { Cetak } \\
\text { tebal } \\
\text { pada } \\
\text { kata cari } \\
\text { di hasil } \\
\text { carian }\end{array}$ & $\begin{array}{l}\text { Cetak tebal } \\
\text { pada kata cari } \\
\text { di hasil carian }\end{array}$ & $\begin{array}{l}\text { Cetak tebal } \\
\text { pada kata } \\
\text { cari di hasil } \\
\text { carian }\end{array}$ & $\begin{array}{l}\text { Cetak } \\
\text { tebal pada } \\
\text { kata cari } \\
\text { di hasil } \\
\text { carian }\end{array}$ & $\begin{array}{l}\text { Cetak } \\
\text { tebal } \\
\text { pada } \\
\text { kata cari } \\
\text { di hasil } \\
\text { carian }\end{array}$ \\
\hline 5 & $\begin{array}{l}\text { Enriched } \\
\text { content }\end{array}$ & $\begin{array}{l}\text { Hanya } \\
\text { cover } \\
\text { buku }\end{array}$ & $\begin{array}{l}\text { Abstrak dan } \\
\text { cover buku }\end{array}$ & $\begin{array}{l}\text { Ada, tapi } \\
\text { terbatas }\end{array}$ & Tidak ada & $\begin{array}{l}\text { Tidak } \\
\text { ada }\end{array}$ \\
\hline
\end{tabular}


Ranking atau urutan hasil pencarian tidak menonjol pada OPAC UIN dan tidak ada fasilitas menu pengaturan ranking (tampilan berdasarkan urutan relevan, tahun terbit, dan lainnya).Hasil pencarian secara default dianggap bahwa hasil yang dimunculkan sudah diurutkan berdasarkan tingkat kesesuaian (relevan) yaitu hasil yang pertama ditampilkan adalah yang paling relevan dan semakin ke bawah semakin kurang relevan.

Pada deskripsi bibliografis yang merupakan bagian penting dalam katalog sebagai wakil dokumen juga masih belum memberikan informasi yang lengkap. UIN Syarif Hidayatullah dan UIN Sumatera Utarasebenarnya memberikan deskripsi yang sudah mendekati ideal yaitu memiliki 8 area sesuai dengan ISBD (international standard book description) akan tetapi, daerah catatan (daerah ke7) hanya memberikan informasi minim yaitu ketersediaan bibliografi dan indeks. Informasi tentang isi buku yang biasanya berupa ringkasan (summary) dan daftar isi, tidak ada di semua OPAC UIN. UIN Syarif Hidayatullah, UIN Ar Raniry danUIN Sumatera Utara memiliki display singkat (briefrecord) dan lengkap (full record) akan tetapi tidak menyediakan deskripsi lengkap. Idealnya display pencarian yang lengkap (full record) memberikan deskripsi yang lengkap. UIN Sunan Gunungdjati dan UIN Sunan Kalijaga bahkan hanya memiliki deskripsi singkat saja. Pada dasarnnya, kapabilitas browsing ini tidak akan berpengaruh pada ketepatan hasil pencarian, akan tetapi akan membantu pemustaka dalam memberikan gambaran dokumen yang ditemukan sehingga mempermudah dalam melakukan seleksi hasil pencarian yang sesuai dengan kebutuhan informasinya. Selain itu, ada satu hal penting dalam fasilitas browsingyaitu ketersediaan subyek pada ruas subyek akan berpengaruh pada proses pencarian yaitu memungkinkan pemustaka untuk melakukan pencarian melalui ruas subyek. Dalam proses temu kembali, pencarian melalui ruas subyek akan memberikan hasil yang lebih tepat karena subyek merupakan wakil dari isi dokumen. Oleh karena itu, ketersediaan ruas subyek akan mempengaruhi ketepatan hasil. OPAC UIN Syarif Hidayatullah memiliki ruas pencarian melalui subyek dan deskripsi bibliografis yang dilengkapi dengan ruas subyek dan keyword, akan tetapi pengisian subyek dan keyword tidak konsisten (kadang diisi di dua ruas, kadang di salah satu ruas), 
maka pencarian dengan ruas subyek menjadi tidak selalu bisa dilakukan. Hal ini menunjukkan bahwa ketersediaan ruas subyek pada deskripsi bibliografis juga mempengaruhi ketepatan hasil pencarian.

Meskipun begitu tiga OPAC UIN yaitu UIN Syarif Hidayatullah, UIN Ar Raniry dan UIN Sumatera Utara menyediakan sampul buku (skripsi dan tesis tidak ada) meskipun tidak ada link yang bisa menghubungkan ke koleksi dalam format elektronik karena memang belum ada koleksi ebook-nya. Fungsi sampul ini pada akhirnya berfungsi sebagai pelengkap saja.

4. Fasilitas tambahan

Fasilitas ini berfungsi untuk membantu dalam proses seleksi hasil pencarian seperti pada fasilitas browsing yang artinya keberadaan fasilitas ini tidak akan mempengaruhi ketepatan hasil pencarian. Akan tetapi fasilitas ini tetap penting disediakan untuk membantu pengguna OPAC menentukan dokumen yang dicari atau bahkan sesuai dengan minatnya. Misalnya saja fasilitas rekomendasi dan bahan-bahan terkait akanmembantu pengguna untuk menemukan dokumen dalam topik sejenis yang mungkin sesuai dengan kebutuhan informasinya. Kontribusi atau review dari pengguna lainnya yang sudah membaca dokumen tertentu akan membantu pengguna dalam memutuskan apakah akan menggunakan dokuemn tersebut atau tidak. Fasilitas ini hanya dimiliki oleh OPAC UIN Syarif Hidayatullah di mana pengguna UIN bisa melakukan review, sedangkan yang non-UIN hanya bisa membaca review.

Tabel 5

Fasilitas Tambahan

\begin{tabular}{|c|l|l|l|l|l|l|}
\hline No & Kategori & $\begin{array}{c}\text { UIN Ar } \\
\text { Raniry }\end{array}$ & $\begin{array}{c}\text { UIN Syarif } \\
\text { Hidayatullah }\end{array}$ & $\begin{array}{c}\text { UIN } \\
\text { Sumatera } \\
\text { Utara }\end{array}$ & $\begin{array}{c}\text { UIN } \\
\text { Bandung }\end{array}$ & $\begin{array}{c}\text { UIN } \\
\text { Sunan } \\
\text { Kalijaga }\end{array}$ \\
\hline 1 & $\begin{array}{l}\text { Rekomen } \\
\text { dasi dan } \\
\text { bahan- } \\
\text { bahan } \\
\text { terkait }\end{array}$ & Tidak ada & $\begin{array}{l}\text { Ada, menu } \\
\text { Find similar }\end{array}$ & Tidak ada & Tidak ada & $\begin{array}{l}\text { Tidak } \\
\text { ada }\end{array}$ \\
\hline 2 & $\begin{array}{l}\text { Kontribus } \\
\text { i user } \\
\text { dalam } \\
\text { rating, }\end{array}$ & Tidak ada & $\begin{array}{l}\text { Ada, pengguna } \\
\text { non UIN } \\
\text { hanya melihat } \\
\text { review, user }\end{array}$ & Tidak ada & Tidak ada & $\begin{array}{l}\text { Tidak } \\
\text { ada }\end{array}$ \\
\hline
\end{tabular}


Marwiyah, Labibah, Evaluasi Kapabilitas Dan Efektivitas Online Public ...

\begin{tabular}{|c|l|l|l|l|l|l|}
\hline $\begin{array}{l}\text { review, } \\
\text { memberik } \\
\text { an } \\
\text { komentar } \\
\text { dan } \\
\text { tagging }\end{array}$ & $\begin{array}{l}\text { UIN bisa } \\
\text { mereview }\end{array}$ & & & \\
\hline 3 & RSS feed & Tidak ada & $\begin{array}{l}\text { Ada tapi tidak } \\
\text { berfungsi }\end{array}$ & Tidak ada & Tidak ada & $\begin{array}{l}\text { Tidak } \\
\text { ada }\end{array}$ \\
\hline
\end{tabular}

\section{Kelengkapan Fasilitas Searching dan Ketepatan Hasil pencarian}

Berdasarkan penghitungan nilai ketepatan (precision) hasil pencarian yang telah peneliti lakukan sebelumnya maka pada dasarnya OPAC di 4 UIN sudah baik yang mencapai nilai antara $81 \%$ sampai $100 \%$ dengan rincian sebagai berikut:

1. UIN Ar Raniry Aceh dengan nilai $81 \%$

2. UIN Syarif Hidayatullah Jakarta dengan nilai 100\% untuk penelusuran advanced dan $48 \%$ untuk penelusuran sederhana

3. UIN Sumatera Utara dengan nilai $81 \%$

4. UIN Sunan Kalijaga dengan nilai $93 \%$

Sedangkan OPAC yang masih memiliki nilai ketepatan yang rendah adalah UIN Sunan Gunungdjati Bandung dengan nilai 33,3\%.

Jika dilihat dari kelengkapan fasilitas pencarian maka OPAC UIN Syarif Hidayatullah memiliki fasilitas paling lengkap. Dengan dua menu pencarian yaitu menu sederhana dan advanced maka memberikan pilihan pada pemustaka untuk melakukan pencarian. Pada dua menu ini, maka terdapat perbedaan nilai ketepatan yang cukup signifikan.Dalam hal ini, fasilitas yang tersedia dalam menu pencarian sederhana tidak lengkap yaitu tidak ada Boolean operator sehingga pencarian dengan menggabungkan dua query tidak bisa dilakukan.Pada pencarian buku tentang sejarah filsafat Islam, pada menu pencarian sederhana hanya bisa menghasilkan dua dan hanya satu hasil yang relevan. Sedangkan pencarian advanced, dengan menggunakan dua konsep kata cari dan dihubungkan dengan operasi Boolean AND maka bisa memberikan hasil yang lebih tepat yaitu 3 buku dan semuanya relevan. Pencarian kata kunci yang sama pada OPAC UIN Sunan 
Kalijaga, UIN Ar Raniry dan UIN Sumatera Utara sebenarnya juga memberikan hasil yang baik yaitu 100\%. Hal ini disebabkan karena ketiga OPAC tersebut memiliki fasilitaslain yaitu frase sehingga pencari informasi bisa menggunakan fasilitas ini untuk membatasi hasil carian. Akan tetapi pada pencarian dengan kata kunci lain, (misalnya sejarah kebudayaan Islam di UIN Ar Raniry) memberikan hasil nilai ketepatan yang kurang bagus. Hal ini disebabkan oleh tidak tersedianya pilihan pencarian melalui ruas cari subyek dan tidak tersedianya subyek pada deskripsi bibliografi.Pada beberapa OPAC tersedia ruas subyek tapi tidak diisi subyeknya sehingga pencarian pada ruas subyek tidak bisa dilakukan.Sebagai alternatif, pengguna OPAC bisa melakukan pencarian dengan menggunakan ruas judul.System hanya menemukan dokumen berdasarkan judul saja. Jika judulnya mengandung kata cari, maka otomatis dokumen tersebut akan ditemukan. Oleh karena itu pada pencarian advanced di OPAC UIN Syarif Hidayatullah pencarian subyek bisa dilakukan dan didukung dengan Boolean operator sehingga nilai ketepatannya tinggi. Pada OPAC UIN Sunan Kalijaga, sebenarnya hanya memiliki menu pencarian sederhana, akan tetapi ketersediaan menu pembatasan hasil cari pada menu setting, memungkinkan untuk melakukan pencarian spesifik sehingga menghasilkan nilai ketepatan yang lebih baik. Dari dua OPAC UIN (Syarif Hidayatullah dan UIN Sunan Kalijaga) yang memiliki fasilitas pencarian yang lebih lengkap ternyata memiliki nilai ketepatan yang lebih baik. Sedangkan OPAC UIN Sunan Gunungdjati tidak memiliki fasilitas pencarian seperti pencarian frase dan Boolean ternyata memberikan hasil ketepatan yang rendah karena system akan mencari semua dokumen yang mengandung salah satu kata cari yang artinya tidak semua hasil yang diperoleh sesuai dengan kata cari yang seharusnya. Pencarian dengan menggunakan kata kunci manajemen dakwah, tidak selalu memberikan dokumen tentang manajemen dakwah, tetapi dokumen tentang dakwah atau tentang manajemen saja.

Dari hasil penelitian ini, maka ada beberapa hasil temuan yang perlu digaris bawahi yaitu:

Fasilitas Pencarian 
Marwiyah, Labibah, Evaluasi Kapabilitas Dan Efektivitas Online Public ...

1. Tidak semua OPAC memiliki dua menu pencarian yaitu pencarian sederhana dan advanced. Hanya UIN Syarif Hidayatullah dan UIN Sumatera Utara yang memiliki dua menu tersebut akan tetapi ada OPAC UIN Sumatera Utara pencarian advanced tidak berfungsi dengan baik. Secara umum fasilitas pencarian paling lengkap dimiliki oleh UIN Syarif Hidayatullah yang memiliki dua menu pencarian dan untuk menu pencarian advanced dilengkapi dengan berbagai fasilitas pencarian. OPAC UIN Sunan Kalijaga meskipun tidak memiliki menu penelusuran advanced akan tetapi memiliki beberapa fasilitas pencarian yang bisa mempersempit hasil carian seperti pembatasan tahun terbit.

2. Fasilitas yang tidak dimiliki OPAC UIN:

a. Menu bantuan (on screen help), hanya UIN Syarif Hidayatullah satusatunya OPAC yang dilengkapi dengan menu bantuan penelusuran

b. Pembatasan. Pada umumnya fasilitas ini disediakan di menu pencarian advanced. UIN Syarif Hidayatullah dan Sumatera Utara yang memiliki fasilitas pencarian ini tidak dilengkapi dengan fasilitas pembatasan yang standar seperti tahun terbit dan Bahasa. Sedangkan OPAC UIN Sunan Kalijaga bisa digunakan untuk melakukan pembatasan pada hasil carian, dan ini seperti model sistem temu kembali informasi saat ini, akan tetapi pilihan format dokumen yang tersediamasih sederhana yaitu jenis dokumen dan tahun terbit saja. Sedangkan menu refine pencarian (perbaikan pencarian) pada system temu kembali informasi yang banyak dikembangkan saat ini lebih detail. Misalnya saja pada OPAC Hollis Harvard University, pembatasan pada menu perbaikan pencarian (refine) mencakup banyak aspek seperti jenis dokumen (buku, book part, artikel, dan lainnya), lokasi perpustakaan (perpustakaan fakultas), subyek, tahun terbit. Dengan pilihan pembatasan yang mencakup banyak aspek ini memberikan pilihan untuk memilih dokumen yang paling sesuai dengan kebutuhan pengguna.

Fasilitas browsing masih terlalu minim sehingga tidak banyak membantu dalam menentukan relevan atau tidaknya dokumen yang ditemukan, misalnya saja 
tidak ada informasi tentang isi pada data bibliografis. Pada beberapa OPAC menyediakan summary atau abstrak atau ringkasan isi buku dan bahkan daftar isi sehingga membantu pengguna untuk mengetahui buku yang akan dipilih.

3. Kelengkapan fasilitas pencarian memberikan pengaruh pada nilai ketepatan Dari lima OPAC perpustakaan UIN, UIN Syarif Hidayatullah Jakarta memiliki fasilitas pencarian yang paling lengkap dan ternyata memiliki nilai ketepatan yang paling tinggi. Begitu juga dengan tiga UIN lainnya yang juga memiliki fasilitas pencarian yang lumayan lengkap meskipun tidak selengkap UIN Syarif Hidayatullah, juga memiliki nilai ketepatan yang lumayan bagus.Fasilitas pencarian yang mempengaruhi nilai ketepatan terutama adalah fasilitas pencarian frase yang berfungsi membuat pencarian lebih spesifik. Empat OPAC UIN yaitu UIN Syarif Hidayatullah, UIN Ar Raniry Aceh, UIN Sumatera Utara dan UIN Sunan Kalijaga Yogyakarta memiliki fasilitas pencarian frase ini dan memiliki nilai precision atau ketepatan yang bagus yaitu $81-100 \%$. Pencarian akan lebih tepat lagi jika OPAC memiliki fasilitas Boolean operator yang memungkinkan penarian kompleks untuk menghasilkan hasil pencarian lebih spesfik. OPAC UIN Syarif Hidayatullah yang memiliki fasilitas ini memiliki nilai ketepatan sempurna yaitu $100 \%$. Sementara OPAC UIN Sunan Gunungdjati yang tidak memiliki fasilitas searching yang memadai, memiliki nilai ketepatan yang rendah yaitu 33,3\%. Hal ini menunjukkan bahwa kelengkapan fasilitas pencarian sedikit banyak mempengaruhi ketepatan hasil pencarian. Hal ini tentu saja tidak mengabaikan adanya kemungkinan atau factor lain yang menyebabkan tinggi rendahnya nilai ketepatan. Misalnya saja pada OPAC UIN Sunan Gunngdjati Bandung, rendahnya nilai ketepatan tidak hanya karena terbatasnya fasilitas pencarian terutama pencarian frase dan boolean operator akan tetapi juga sistem pengindeksan yaitu pengindeksan huruf demi huruf. Akibatnya, kata cari yang digunakan untuk penelusuran dibaca per huruf sehingga memberikan hasil yang cukup banyak meskipun tidak relevan. 
Marwiyah, Labibah, Evaluasi Kapabilitas Dan Efektivitas Online Public ...

\section{PENUTUP}

Fasilitas searching pada OPAC UIN masih belum sepenuhnya lengkap dan keberadaan fasilitas frase dan Boolean sangat penting untuk menjadikan pencarian pada system temu kembali informasi lebih efektif. Danfasilitas searching ini memberikan pengaruh pada nilai ketepatan terutama dengan ketersediaan fasilitas proximity yang dalam hal ini adalah pencarian frase dan Boolean operator. Hal ini ditunjukkan dengan nilai ketepatan OPAC UIN yang memiliki fasilitas pencarian (empat UIN) mempunyai nilai ketepatan yang tinggi (81\%, 93\% dan 100\%) sedangkan yang tidak memiliki fasilitas searching yang memadai memiliki ketepatan rendah $(33,3 \%)$. Di sisi lain, fasilitas browsing tidak mempengaruhi nilai ketepatan akan tetapi fasilitas ini membantu pengguna dalam menentukan pilihan hasil cari yang relevan dengan kebutuhan informasinya. Oleh karena itu kelengkapan fasilitas browsing diperlukan oleh pengguna OPAC seperti link ke ebook (jika ada) dan daftar isi. Selain itu, ada satu elemen penting yang tidak tersedia di OPAC UIN (kecuali UIN Syarif Hidayatullah) yaitu menu bantuan yang membantu pengguna memahami cara menggunakan OPAC sehingga pengguna bisa melakukan pencarian dengan maksimal. OPAC UIN Sunan Kalijaga yang memiliki beberapa fasilitas penting akan tetapi tidak dilengkapi dengan tersedianya menu bantuan akan menjadikan tidak terpakainya fasilitas tersebut dan pencarian spesifik untuk menghaislkan ketepatan yang tinggi tidak bisa tercapai.

\section{DAFTAR RUJUKAN}

Baeza-Yates, Ricardo, and Berthier Ribeiro-Neto. Modern Information Retrieval. Essex: ACM Press, 2004.

Breeding, Marshall. "Introduction to "The next Generation Library Catalog." Library Technology Reports 43, no. 4 (2007): 5-14.

Chowdhury, G.G. Introduction to Modern Information Retrieval. London: Facet, 2004.

Kowalski, Gerald J., Mark T. Maybury, and Mark T. Information Storage and Retrieval Systems. New York: Kluwer Academic Publisher, 2002.

Large, Andrew, Lucy A. Tedd, and R. J. Hartley. Digital Libraries: Principles and Practice in a Global Environment. Munchen: K.G. Saur, 2005. . Seeking in the Online Age: Principles and Practice. Munchen: KG Saur, 2001. 
Madhusudhan, Margam, and Shalini Aggarwal. "Web-Based Online Public Access Catalogues of IIT Libraries in India: An Evaluative Study." Program 45, no. 4 (2011): 415-38.

Olson, Hope A., and John J. Boll. Subject Analysis in Online Catalogues 2nd Ed. Englewood: Libraries Unlimited, 2001.

Rowley, Jennifer E. Organizing Knowledge: An Introduction to Managing Access to Information Retrieval2nd Ed. Vermon: Ashgate Publishing, Ltd., 1992.

Sugiyono. Metode Penelitian Kombinasi (Mixed Methods). Bandung: Alfabeta, 2013.

Wells, David. "What Is a Library OPAC?" The Electronic Library 25, no. 4 (2007): $386-394$. 